\title{
Jochen Heinrichs: March 14, 1969-April 22, 2018
}

\author{
Michael Krings ${ }^{1} \cdot$ Harald Schneider ${ }^{2,3} \cdot$ Julia Bechteler $^{4} \cdot$ Kathrin Feldberg $^{5} \cdot$ Susanne S. Renner ${ }^{5}$. \\ Alfons Schäfer-Verwimp ${ }^{6}$. Alexander R. Schmidt ${ }^{7}$
}

Received: 16 May 2018 / Accepted: 17 May 2018 / Published online: 2 June 2018

(c) Springer-Verlag GmbH Austria, part of Springer Nature 2018

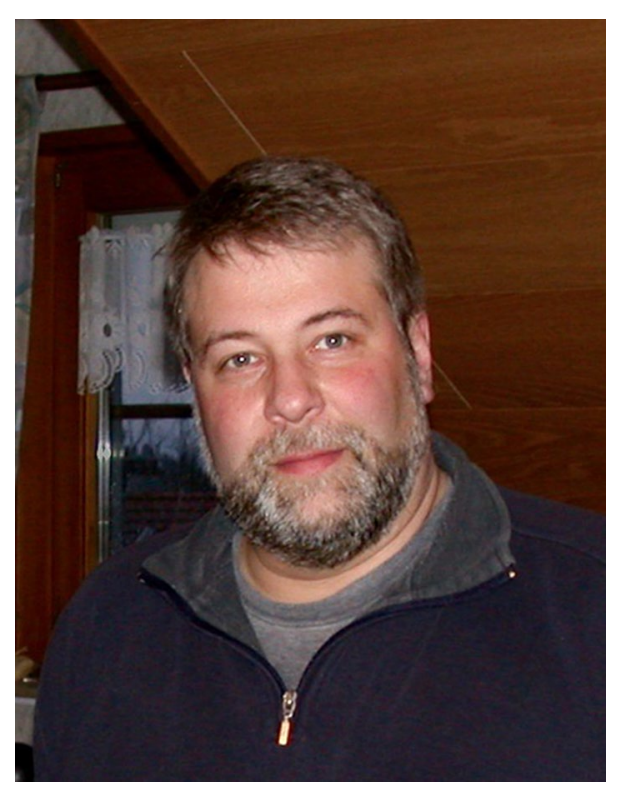

Jochen Heinrichs in 2015

Dr. Jochen Heinrichs, full professor for Molecular Systematics of Lower Plants at the Ludwig-Maximilians-University of Munich, Germany, passed away on April 22, 2018, after
10 months of battling an autoimmune disease. A committed scientist and warm-hearted, selfless person, Jochen was an internationally renowned bryologist, paleobryologist, and plant evolutionary biologist, whose premature death has been devastating to his family, friends, colleagues, and students.

Jochen was born in 1969 in Mönchengladbach-Reindahlen, a city located in the Rhine-Ruhr metropolitan region of Germany, close to Düsseldorf. Although he later lived and pursued his scientific training and career in Lower Saxony and Bavaria, far away from his hometown, Jochen remained a proud advocate of his Rhenish heritage. Jochen's interest in nature and natural sciences began early in life. He started bird photography during his senior school years and cultivated a wide variety of plants in the family garden, including native orchids. He also worked in a landscaping company where he began to develop a keen interest in botany and especially bryology.

Jochen received his academic training from the HeinrichHeine University in Düsseldorf (1989-1996) and earned a master's degree in biology, with a thesis on Syntrichia (formerly Tortula). He then moved to the Georg-August University at Göttingen for graduate studies (1996-2002) and earned his doctoral title from that university in 2002
Electronic supplementary material The online version of this article (https://doi.org/10.1007/s00606-018-1521-4) contains supplementary material, which is available to authorized users.

Michael Krings

m.krings@1rz.uni-muenchen.de

1 Department für Geo- und Umweltwissenschaften, Paläontologie und Geobiologie, Ludwig-MaximiliansUniversität, and SNSB-Bayerische Staatssammlung für Paläontologie und Geologie, Munich, Germany

2 Center for Integrative Conservation, Xishuangbanna Tropical Botanical Garden, Menglun County, Yunnan, China

3 Department of Life Science, Natural History Museum, London, UK
4 Nees-Institut für Biodiversität der Pflanzen, Rheinische Friedrich-Wilhelms-Universität Bonn, Bonn, Germany

5 Systematische Botanik und Mykologie, Ludwig-Maximilians-Universität München, Munich, Germany

6 Herdwangen-Schönach, Germany

7 Department of Geobiology, University of Göttingen, Göttingen, Germany 
(under the supervision of S. Robbert Gradstein; thesis title: A taxonomic revision of Plagiochila sect. Hylacoetes, sect. Adiantoideae and sect. Fuscoluteae in the Neotropics with a preliminary subdivision of Neotropical Plagiochilaceae into nine lineages), as well as his venia legendi (Habilitation) in 2007. He was appointed curator of the Göttingen University Herbarium (GOET) of the Albrecht-von-Haller Institute in 2001 and since 2009 also served as a principal investigator of the Courant Research Centre "Geobiology" at Göttingen University. During his tenure as curator, Jochen not only reorganized the collection, but also initiated the establishment of a digital herbarium, which he supervised until he left Göttingen for Munich in 2013 to assume the position of professor for Molecular Systematics of Lower Plants at the Ludwig-Maximilians-University.

Liverworts were one of Jochen's great passions from day one of his career and, consequently, he devoted most of his time to collecting and studying these plants. He undertook far-reaching expeditions to collect his study objects, including to Bolivia (1997, with Hermann Anton and Jochen Müller), Costa Rica (1999, again with Hermann Anton as well as IngoHolz), and Ecuador (2004, with Rosemary Wilson and Alfons Schäfer-Verwimp). Liverworts collected during these expeditions are kept in Jochen's Bryophyta Exsiccata Generis Plagiochilae in 6 fascicles (300 numbers). Moreover, Jochen gathered an impressive private collection of bryophytes (predominantly from Europe) as well as flowering plants that he, for the greater part, deposited in the herbaria of the University of Munich, M and MSB.

Jochen published more than 200 research articles (see Bibliography in Online Resource 1), which makes him one of the most prolific contemporary bryologists worldwide. His most influential contribution addresses the taxonomy of Plagiochila and provides new insights into this widespread but hitherto poorly known genus (e.g., Heinrichs et al. 1998a, b, 2000; Heinrichs 2002a, b). Other major contributions to liverwort systematics and taxonomy focused on molecular phylogeny (e.g., Heinrichs et al. 2012a; Feldberg et al. 2010, 2016; Carter et al. 2016), classification of Lejeuneaceae (e.g., Wilson et al. 2004; Heinrichs et al. 2014a, b, c, d, 2015a, b; Bechteler et al. 2016a, b), cryptic speciation in bryophytes (e.g., Kreier et al. 2010; Heinrichs et al. 2011), and diversification patterns in leafy liverworts (e.g., Heinrichs et al. 2013; Bechteler et al. 2016c). For the best paper published in The Bryologist in 2005, Jochen was awarded the Sullivant Award of the American Bryological and Lichenological Society. However, characterizing Jochen solely as a liverwort bryologist does not do him justice. Rather, his scientific interests were many and spanned a diverse spectrum of topics and organisms ranging from fungi to flowering plants such as Hieracium to the poorly known, but common moss genus Syntrichia. To study the latter, Jochen had to climb Eternit roofs for which he went to great lengths in villages along the hills of the Mosel valley.

By about 2008, Jochen became increasingly interested in, and fascinated by, fossil bryophytes, especially the copious record of these plants in amber, and in the possibility of incorporating fossil bryophytes as constraint into molecularclock analyses and biogeographic and trait change reconstructions. He studied and revised numerous amber fossils of leafy liverworts and mosses (e.g., Heinrichs et al. 2015b, 2016a, b, 2017a, b) and more recently also of ferns (e.g., Schneider et al. 2016; Regalado et al. 2016, 2017, 2018). Research on amber fossils evolved into a particular passion; private acquisitions and loans from museum and university collections, as well as from other private collectors, piled up in his laboratory, forming one of the most significant compilations worldwide of amber fossils of seedless land plants. One of Jochen's mentors, Riclef Grolle (1934-2004), once stated "running the gauntlet of taxonomy in the vast abysses of geologic time is a particular challenge" (cited in Heinrichs et al. 2012b). Jochen not only embraced this challenge, but also expanded the task by placing the results from his research on amber-preserved fossils into a broader evolutionary context. His research on amber fossils resulted in more than 40 papers on liverworts and mosses, as well as ferns, fungi, and lichens (e.g., Hartl et al. 2015; Heinrichs et al. 2015b; Kaasalainen et al. 2015; Schneider et al. 2016). Many of these papers have opened new avenues of research and have set standards in the investigation of amber fossils and their incorporation in phylogenetics. For example, by combining molecular phylogenies with fossil evidence from amber, Jochen was able to demonstrate that certain extant species of seedless land plants date back to the Miocene, but not the Paleogene as had been suggested (e.g., Heinrichs et al. 2015b, c). One of Jochen's fellow bryologists, Jeff Duckett of Queen Mary University, London, Great Britain, recently commented (to M. Krings, email of May 5, 2018): "I knew Jochen best as a reviewer of many of his papers over many years. These were always a pleasure to read and without exception I recommended publication: at most I suggested just very minor changes. He was a superb taxonomist, probably stemming from his first-class knowledge of bryophytes in the field, and this was invariably reflected in his holistic appraisal of fossil liverworts." One of the last manuscripts Jochen was working on is "A comprehensive assessment of the fossil record of liverworts in amber," an invited contribution to the commemorative volume for the late Thomas N. Taylor (1937-2016). Although Jochen was unable to complete the manuscript in person, he oversaw the final stages of its production from his hospital bed and repeatedly expressed satisfaction with the outcome. Unfortunately, Jochen did not live to see the published version of his paper (Heinrichs et al. 2018). 

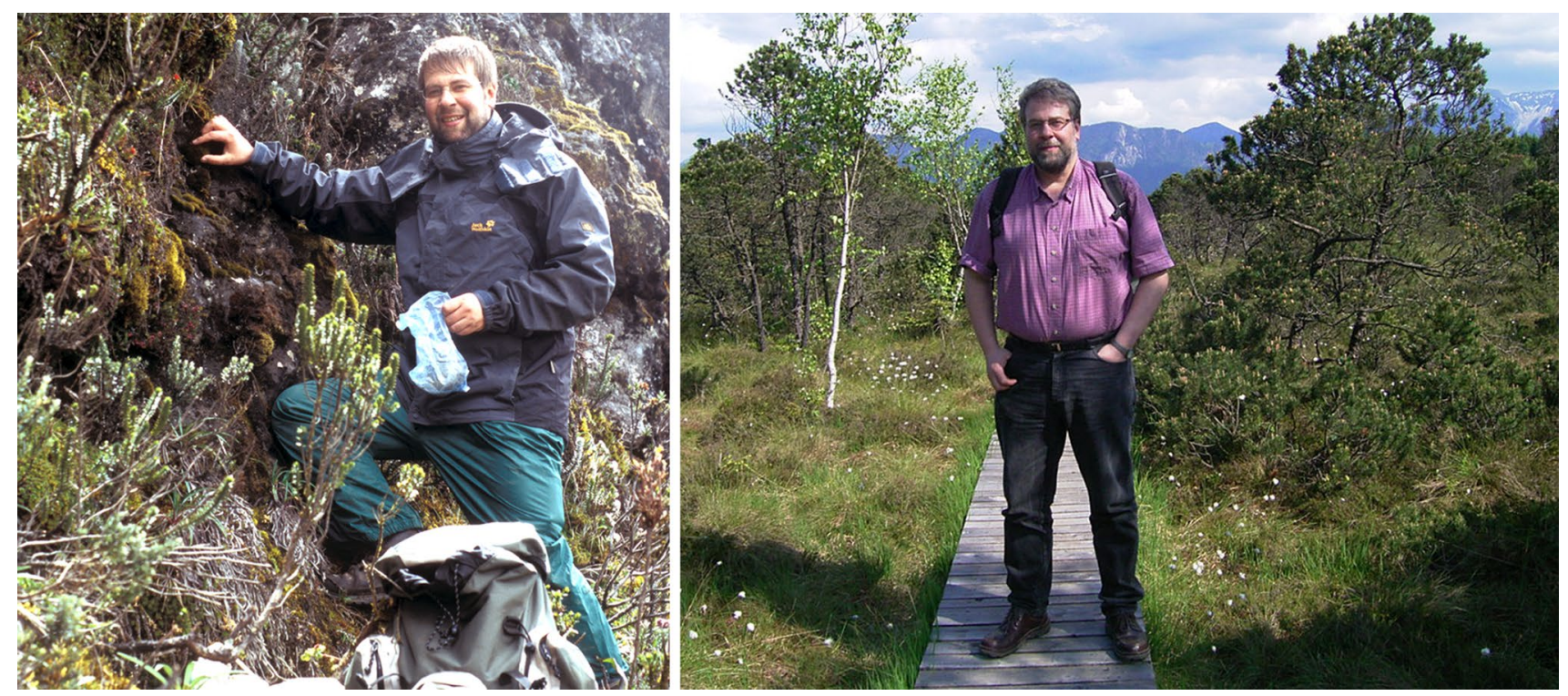

In the field. Left: Ecuador 2004, Jochen in the Polylepis forest at the Papallacta Pass. Right: Murnauer Moos, Bavaria, 2013, Jochen during a field trip

Jochen was an inspired teacher, advisor, and mentor, who always found time for his students to discuss science or just for a cup of coffee and a chat. When and wherever assistance was needed, Jochen was ready to help with words and deeds. Certainly, he had high expectations, but through his unselfishness and helpful demeanor he made it easy, often even enjoyable, for students to dive into the exciting world of science, expand their skills, and gain experience. Moreover, Jochen allowed his students to participate in publications very early in their careers. His generous approach regarding co-authorship made it possible for many to contribute to a variety of studies and learn about many topics and techniques in plant science. Jochen will be remembered by all who had the privilege to interact with him for his desire to achieve the highest quality in research, education, and outreach, his devotion to the training of young plant biologists, and, last but not least, for his humorous style of lecturing and teaching.

Another important segment of Jochen's remarkable career that deserves mention concerns his dedicated service to the scientific community. He served as an editorial board member of several scientific journals, including Plant Systematics and Evolution (since 2009), Cryptogamie, Bryologie (since 2002), Journal of Bryology (since 2013), and Nature Scientific Reports (since 2014), and as Editor-in-Chief of the publication series Bryophytorum Bibliotheca (since 2005). As an editor and manuscript reviewer, "he [Jochen] had very sound judgment and was always courteous and considerate to authors even when their work had serious shortcomings" (Jeff Duckett, email to M. Krings of May 5, 2018). Jochen was also a member of the Committee for Bryophytes of the International Association for Plant Taxonomy (1999-2005) and an executive board member of the GeoBio-Center ${ }^{\text {LMU }}$ (since 2016). His commitment to the society of Germanspeaking plant biologists is evident from his long-term service as vice-chairman of the Systematics sections of the German Botanical Society (since 2008). All these services to the community, Jochen conducted conscientiously, with enthusiasm, and with distinction. Unfortunately, and far too often in recent years, he put work and service before his own well-being and ignored signs of declining health.

Friends, colleagues, and students will keep Jochen in grateful remembrance. He was a person of many passionsand he readily allowed others to join in. For example, he encouraged colleagues and students to visit local museums to explore the works of art, especially paintings. His love for, and profound knowledge of, the visual arts was also manifested in his exquisite private collection of German early twentieth-century prints and paintings. Jochen was particularly fond of (classic) modernism represented by Wassily Kandinsky, Franz Marc, and Lyonel Feininger. He was the proud owner of several drawings, woodcuts, lithographic prints, and paintings by artists such as Joan Miró, Erich Heckel, Georges Braque, Max Ernst, Otto Modersohn, and Salvador Dalí. However, Jochen was likewise interested in the works of less famous artists, and one of us had the pleasure to join Jochen and receive first-hand expert insights during a visit to the Tate Britain and the National Portrait Gallery in London a few years ago. The actual purpose of this trip was not art, of course, but rather to attend 
a bryological symposium at the Natural History Museum during which Jochen never failed until late to come up with "cunning plans" to address all the issues that mattered to him. Jochen's ability to enliven even the most jejune meeting with his cheerful Rhenish humor and fondness for the small pleasures of life will be sorely missed. Going into a restaurant in Munich, Jochen was asked by a colleague if he was a vegetarian to which came the immediate reply "Do I look like a vegetarian?"

We will miss Jochen as a mentor, colleague, and friend, and honor his legacy through the continuation of the work that he so loved.

\section{Information on Electronic Supplementary Mate- rial}

Online Resource 1. Jochen Heinrichs Bibliography.

\section{References}

Bechteler J, Lee GE, Schäfer-Verwimp A, Pócs T, Peralta DF, Renner MAM, Schneider H, Heinrichs J (2016a) Towards a monophyletic classification of Lejeuneaceae IV: reinstatement of Allorgella, transfer of Microlejeunea aphanella to Vitalianthus and refinements of the subtribal classification. Pl Syst Evol 302:187-201

Bechteler J, Lee GE, Schäfer-Verwimp A, Renner MAM, Peralta DF, Heinrichs J (2016b) Towards a monophyletic classification of Lejeuneaceae V: the systematic position of Pictolejeunea. Phytotaxa 280:259-270

Bechteler J, Schäfer-Verwimp A, Lee GE, Feldberg K, Pócs T, Peralta DF, Renner MAM, Heinrichs J (2016c) Geographical structure and narrow species ranges in a pantropical clade of epiphyllous leafy liverworts. Ecol Evol 7:638-653

Carter BE, Larraín J, Manukjanová A, Shaw B, Shaw AJ, Heinrichs J, de Lange P, Suleiman M, Thouvenot L, von Konrat M (2016) Species delimitation and biogeography of a southern hemisphere liverwort clade, Frullania subgenus Microfrullania (Frullaniaceae, Marchantiophyta). Molec Phylogen Evol 107:16-26

Feldberg K, Váña J, Long DG, Shaw AJ, Hentschel J, Heinrichs J (2010) A phylogeny of Adelanthaceae (Jungermanniales, Marchantiophyta) based on nuclear and chloroplast DNA markers, with comments on classification, cryptic speciation and biogeography. Molec Phylogen Evol 55:293-304

Feldberg K, Váňa J, Krusche J, Kretschmann J, Patzak SDF, PérezEscobar OA, Rudolf NR, Seefelder N, Schäfer-Verwimp A, Long DG, Schneider H, Heinrichs J (2016) A phylogeny of Cephaloziaceae (Jungermanniopsida) based on nuclear and chloroplast DNA markers. Organisms Divers Evol 16:727-742

Hartl C, Schmidt AR, Heinrichs J, Seyfullah LJ, Schäfer N, Gröhn C, Rikkinen J, Kaasalainen U (2015) Lichen preservation in amber: morphology, ultrastructure, chemofossils and taphonomic alteration. Fossil Rec 18:127-135

Heinrichs J (2002a) A taxonomic revision of Plagiochila sect. Hylacoetes, sect. Adiantoideae and sect. Fuscoluteae in the Neotropics with a preliminary subdivision of Neotropical Plagiochilaceae into nine lineages. Bryophyt Biblioth 58(Append. 1-5):1-184

Heinrichs J (2002b) New synonyms in Plagiochila II. Cryptog Bryol 23:351-353
Heinrichs J, Gradstein SR, Grolle R (1998a) A revision of the neotropical species of Plagiochila (Dumort.) Dumort. (Hepaticae) described by Olof Swartz. J Hattori Bot Lab 85:1-32

Heinrichs J, Grolle R, Drehwald U (1998b) The conspecifity of Plagiochila killarniensis Pearson and P. bifaria (Sw.) Lindenb. (Hepaticae). J Bryol 20:495-528

Heinrichs J, Anton H, Gradstein SR, Mues R (2000) Systematics of Plagiochila sect. Glaucescentes Carl (Hepaticae) from tropical America: a morphological and chemotaxonomical approach. Pl Syst Evol 220:115-138

Heinrichs J, Kreier HP, Feldberg K, Schmidt AR, Zhu RL, Shaw B, Shaw AJ, Wissemann V (2011) Formalizing morphologically cryptic biological entities: new insights from DNA-taxonomy, hybridization and biogeography in the leafy liverwort Porella platyphylla (Jungermanniopsida, Porellales). Amer J Bot 98:1252-1262

Heinrichs J, Bombosch A, Feldberg K, Kreier HP, Hentschel J, Eckstein J, Long D, Zhu RL, Schäfer-Verwimp A, Schmidt AR, Shaw B, Shaw AJ, Váňa J (2012a) A phylogeny of the northern temperate leafy liverwort genus Scapania (Scapaniaceae, Jungermanniales). Molec Phylogen and Evol 62:973-985

Heinrichs J, Reiner-Drehwald ME, Feldberg K, von Konrat M, Hentschel J, Váňa J, Nascimbene PC, Grimaldi DA, Schmidt AR (2012b) The leafy liverwort Frullania in the Cretaceous amber forest of Myanmar. Rev Palaeobot Palynol 169:21-28

Heinrichs J, Dong S, Schäfer-Verwimp A, Pócs T, Feldberg K, Czumaj A, Schmidt AR, Reitner J, Renner MAM, Hentschel J, Stech M, Schneider H (2013) Molecular phylogeny of the leafy liverwort Lejeunea (Porellales): evidence for a Neotropical origin, uneven distribution of sexual systems and insufficient taxonomy. PLoS ONE 8:e82547

Heinrichs J, Czumay A, Dong S, Scheben A, Schäfer-Verwimp A, Peralta DF, Feldberg K, Schmidt AR, Schneider H (2014a) The Bromeliaceae tank dweller Bromeliophila (Lejeuneaceae, Porellales) is a member of the Cyclolejeunea-Prionolejeunea clade. Pl Syst Evol 300:63-73

Heinrichs J, Dong S, Schäfer-Verwimp A, Peralta DF, Feldberg K, Schmidt AR, Schneider H (2014b) Towards a monophyletic classification of Lejeuneaceae II: subtribes Pycnolejeuneinae and Xylolejeuneinae subt. nov., transfer of Otolejeunea to Lepidolejeuninae, and generic refinements. Phytotaxa 163:61-76

Heinrichs J, Schäfer-Verwimp A, Boxberger J, Feldberg K, Solórzano Kraemer MM, Schmidt AR (2014c) A fossil species of Ceratolejeunea preserved in Miocene Mexican amber. The Bryologist 117:10-14

Heinrichs J, Schäfer-Verwimp A, Czumay A, Dong S, Scheben A, Feldberg K, Schneider H (2014d) Towards a monophyletic classification of Lejeuneaceae I: subtribe Leptolejeuneinae subtr. nov. Phytotaxa 156:165-174

Heinrichs J, Feldberg K, Bechteler J, Scheben A, Czumay A, Pócs T, Schneider H, Schäfer-Verwimp A (2015a) Integrative taxonomy of Lepidolejeunea (Porellales, Jungermanniopsida): ocelli allow the recognition of two neglected species. Taxon 64:216-228

Heinrichs J, Kettunen E, Lee GE, Marzaro G, Pócs T, Ragazzi E, Renner MAM, Rikkinen J, Sass-Gyarmati A, Schäfer-Verwimp A, Scheben A, Solórzano Kraemer M, Svojtka M, Schmidt AR (2015b) Lejeuneaceae (Marchantiophyta) from a species-rich taphocoenosis in Miocene Mexican amber, with a short survey of liverworts in amber. Rev Palaeobot Palynol 221:59-70

Heinrichs J, Scheben A, Lee GE, Váňa J, Schäfer-Verwimp A, Krings M, Schmidt AR (2015c) Molecular and morphological evidence challenges the records of the extant liverwort Ptilidium pulcherrimum in Eocene Baltic amber. PLoS ONE 10:e0140977

Heinrichs J, Scheben A, Bechteler J, Lee GE, Schäfer-Verwimp A, Hedenäs L, Singh H, Pócs T, Nascimbene PC, Peralta DF, Renner MAM, Schmidt AR (2016a) Crown group Lejeuneaceae and 
pleurocarpous mosses in early Eocene (Ypresian) Indian Amber. PLoS ONE 11:e0156301

Heinrichs J, Schmidt AR, Schäfer-Verwimp A, Bauerschmidt L, Neumann C, Gröhn C, Krings M, Renner MAM (2016b) Revision of the leafy liverwort genus Radula (Porellales, Jungermanniopsida) in Baltic and Bitterfeld amber. Rev Palaeobot Palynol 235:157-164

Heinrichs J, Feldberg K, Bechteler J, Müller P, Renner MAM, Váňa J, Schäfer-Verwimp A, Schmidt AR (2017a) A fossil genus of the Frullaniaceae (Porellales, Jungermanniopsida) from the midCretaceous of Myanmar. Cretaceous Res 74:223-226

Heinrichs J, Feldberg K, Müller P, Schäfer-Verwimp A, von Konrat M, Ilsemann B, Krings M (2017b) Frullaniapinnata spec. nov. (Frullaniaceae, Porellales), a new leafy liverwort in mid-Cretaceous Burmese amber from Myanmar. Cretaceous Res 78:56-60

Heinrichs J, Feldberg K, Bechteler J, Regalado L, Renner MAM, Schäfer-Verwimp A, Gröhn C, Müller P, Schneider H, Krings M (2018) A comprehensive assessment of the fossil record of liverworts in amber. In: Krings M, Harper CJ, Cuneo NR, Rothwell GW (eds) Transformative paleobotany, papers to commemorate the life and legacy of Thomas N. Taylor. Academic Press/Elsevier Inc, Burlington/London (in press)

Kaasalainen U, Heinrichs J, Krings M, Myllis L, Grabenhorst H, Rikkinen J, Schmidt AR (2015) Alectorioid morphologies in Paleogene lichens: new evidence and re-evaluation of the fossil Alectoria succini Mägdefrau. PLoS ONE 10:e0129526

Kreier HP, Feldberg K, Mahr F, Bombosch A, Schmidt AR, Zhu RL, von Konrat M, Shaw B, Shaw AJ, Heinrichs J (2010) Phylogeny of the leafy liverwort Ptilidium: cryptic speciation and shared haplotypes between the Northern and Southern Hemispheres. Molec Phylogen Evol 57:1260-1267

Regalado L, Schmidt AR, Müller P, Kobbert MJ, Schneider H, Heinrichs J (2016) The first fossil of Lindsaeaceae (Polypodiales) from the Cretaceous amber forest of Myanmar. Cretaceous Res 72:8-12

Regalado L, Schmidt AR, Appelhans MS, Ilsemann B, Schneider H, Krings M, Heinrichs J (2017) A fossil species of the enigmatic early polypod fern genus Cystodium (Cystodiaceae) in Cretaceous amber from Myanmar. Sci Rep 7:14615

Regalado L, Schmidt AR, Krings M, Bechteler J, Schneider H, Heinrichs J (2018) Fossil evidence of eupolypod ferns in the midCretaceous of Myanmar. P1 Syst Evol 304:1-13

Schneider H, Schmidt AR, Heinrichs J (2016) Burmese amber fossils bridge the gap in the Cretaceous record of polypod ferns. Perspect in Pl Ecol Evol Syst 18:70-78

Wilson R, Gradstein SR, Heinrichs J, Groth H, Ilkiu-Borges AL, Hartmann FA (2004) Phylogeny of Lejeuneaceae: a cladistic analysis of chloroplast gene rbcL sequences and morphology with preliminary comments on the mitochondrial nad4-2 spacer region. In: Goffinet B, Hollowell V, Magill R (eds) Molecular systematics of bryophytes (monographs in systematic botany from the missouri botanical garden, vol 98, Missouri Botanical Garden Press, St. Louis, pp 189-202 